\title{
Research on Urban Community Public Space Design Based on Children's Psychological Needs-A Case Study and Survey of Chengdu Yulin East Road
}

\author{
Chaoyi You \\ School of Urban Planning and Architecture, Southwest Minzu University, Chengdu, China \\ Email: 651645399@qq.com
}

How to cite this paper: You, C.Y. (2019) Research on Urban Community Public Space Design Based on Children's Psychological Needs-A Case Study and Survey of Chengdu Yulin East Road. Open Journal of Social Sciences, 7, 444-457.

https://doi.org/10.4236/jss.2019.78032

Received: June 24, 2019

Accepted: August 27, 2019

Published: August 30, 2019

Copyright $\odot 2019$ by author(s) and Scientific Research Publishing Inc. This work is licensed under the Creative Commons Attribution International License (CC BY 4.0).

http://creativecommons.org/licenses/by/4.0/

(c) (i) Open Access

\begin{abstract}
Viewing from the theory of child psychology, there is close connection between space environment and psychological development. Community public space, as children's after-school micro-environment, is an important place for the shaping of cognitive ability, personality and social process. Based on this background, taking the communities of Yulin East Road in Wuhou District of Chengdu as the research object, within the radius of one kilometer radiation centered on Yulin East Road, this paper conducted a survey on the current situation of street space, square space and courtyard space and found that there is inadequate recreational facilities in current spaces, together with the unreasonable traffic layout, which cannot meet the various needs of children. In the end, the planning suggestions are proposed based on the different scales of spaces. Children are the major concerns in the urban development. The introduction of child developmental psychology into the design of urban open spaces, it should become an urgent need for the reshaping of the vitality of urban open spaces and the recovery of children's rights.
\end{abstract}

\section{Keywords}

Community Public Space, Street, Square, Courtyard, Child Psychology

\section{Introduction}

The present large-scale urbanization process leads to the shortage of land resources, the excessive concentration of population in cities, and the insufficient public space area per person, so it is difficult to build a "human-oriented" 
friendly city. As a milestone of transition from increment to inventory, urban planning in the new era pays more attention to the guiding role of social public policy, it requires that the interests of vulnerable groups in society should be actively safeguarded. In 1996, the concept of "child-friendly cities" was first put forward at the Second UN Conference on Human Settlements. It suggested that the basic needs of children should be incorporated into the planning of districts or cities to fulfill children's needs and rights on environment, society and psychology, to provide a beneficial social and spatial environment for children, so as to help them develop their own creativity and achieve the healthy development of individuality [1]. Children are an important component of the city and the public open spaces are the main places for children to play and make friends, while the current urban public space cannot meet such a need for children [2]. As a new planning unit, "community" belongs to the basis of urban infrastructure planning and guides the design of public space at different scales. Based on the psychological needs of children, this paper investigates the public space of Yulin East Road Community in Chengdu, and makes some reform and design according to this conclusion, further more gives some suggestions in the perspective of planning.

\section{Survey of Study}

\subsection{Study Scope}

The survey area of this study is located in the Yulin Road area of Wuhou District in Chengdu. The specific scope of this study is limited within one kilometer radiation circle centered on the typical Yulin East Road (as shown in Figure 1). The field research is conducted for the community public open space within the scope.

\subsection{Research Methods and Technical Route}

Field research and individual interviews were used in this study to make an investigation on the current situation of public open space in Yulin East Road

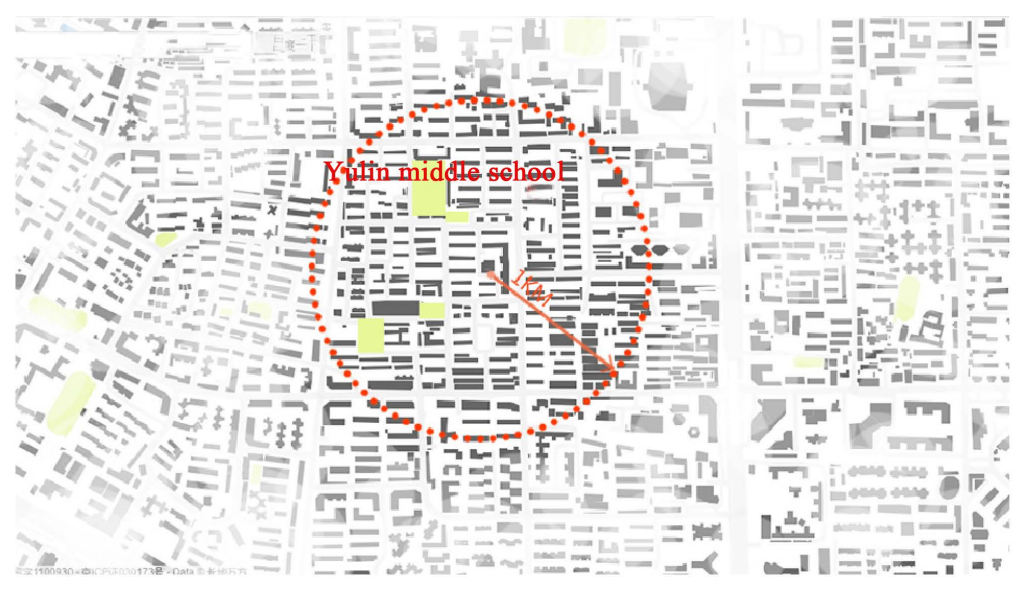

Figure 1. Sketch map of study scope (Image source: drawn by author). 
Community. Based on the three spatial scales of streets, squares and courtyards, this paper investigates the usage and the existing problems of the public space in Yulin East Road Community, and puts forward the reform and design strategies for the open space of Yulin East Road community according to the psychological needs of children.

The research route what we adopted is: the triad planning strategy of "point, line and plane", that is, children are taken as the center, block-square-courtyard strung, taking Yulin East Road Community as radiation plane (as shown in Figure 2).

\section{Psychological Needs of Children in Different Age Stages}

\subsection{Psychological and Behavior Characteristics of Children in Different Age Stages}

Child developmental psychology clarifies the important influence of environment on children's psychological development, while environmental psychology expounds that behavior is the medium connecting space environment and user psychology, and the environment-behavior phenomenon is closely related to architectural design [3]. As a micro-environment, the most direct living space outside of campus for children, community outdoor public space is closely related to the development of child mental health. From birth to school age to childhood, with the enhancement of children's social cognitive ability, continuous development of personality, and their self-control, their needs for peer relationship are improved. The precondition of environmental renovation is the analysis of psychological needs. The following table shows the psychological and behavior characteristics of children in different age stages. (Table 1)

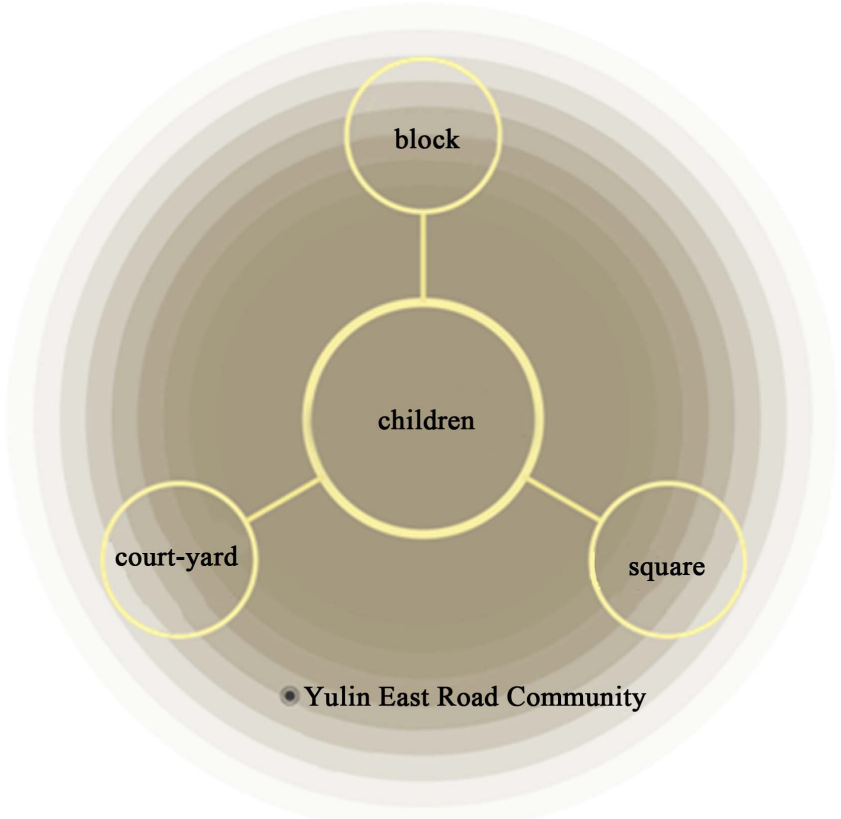

Figure 2. Sketch of research strategy (Image source: drawn by author). 
Table 1. Psychological and behavior characteristics of children in different age stages.

\begin{tabular}{|c|c|c|}
\hline Age Stages & Psychological characteristics & behavior characteristics \\
\hline $\begin{array}{l}\text { Birth to Age } 3 \\
\text { (infantstage) }\end{array}$ & $\begin{array}{l}\text { Stage of sense-locomotor development: } \\
\text { During this period, babies always achieve their development } \\
\text { through constant feedback. For example, their eyes can } \\
\text { perceive the movement of the hands, having fun on } \\
\text { it and giving feedback to brain, keeping hands } \\
\text { moving continuously in order to continue to perceive. }\end{array}$ & $\begin{array}{l}\text { The way of mother-centered parenting. } \\
\text { Children need the accompany of adults to } \\
\text { explore the world by grasping, crawling and } \\
\text { walking. Start the initial game activities, } \\
\text { or objects or toys, with less imaginary } \\
\text { components in the games. }\end{array}$ \\
\hline $\begin{array}{c}\text { Age } 3-5,6 \\
\text { (earlychildhood) }\end{array}$ & $\begin{array}{l}\text { Period of Subjectivity or Personality: } \\
\text { In order to break away from the situation that they recognize } \\
\text { themselves difficultly, there emerged three stages among children. } \\
\text { In the first stage, the game of alternating roles begins to disappear, } \\
\text { and children would like to be self-important; in the second stage, } \\
\text { children have a new need, that is, to show off themselves and } \\
\text { to let others acknowledge their advantages; in the third stage, } \\
\text { there comes a new transition, the advantages finding } \\
\text { from the children cannot satisfy themselves any more, they } \\
\text { need to realize self-decoration through the advantages of others. }\end{array}$ & $\begin{array}{l}\text { With the capability to move independently, } \\
\text { the children are active, but usually they } \\
\text { need the accompany of their parents. } \\
\text { They are good at simple and safe games. } \\
\text { They like creative handwork and } \\
\text { activity-based games etc. }\end{array}$ \\
\hline $\begin{array}{c}\text { Age } 6-11,12 \\
\text { (Childhood) }\end{array}$ & $\begin{array}{l}\text { Period of Objectivity: } \\
\text { Children's main interests are directed to the external things } \\
\text { because of the expansion of children's communication, } \\
\text { the influence of school education and the development of their } \\
\text { intelligence. With the growth of age, children's views on external } \\
\text { things are no longer subjective, unilateral or isolated, instead } \\
\text { with the formation of objective and systematic cognitive system. }\end{array}$ & $\begin{array}{l}\text { There are great demand for outdoor } \\
\text { activities. Children like to play with peers } \\
\text { and their interests in games are gradually } \\
\text { replaced by sports with the enhancement } \\
\text { of competitive awareness and more } \\
\text { greater interests in intellectual activities. }\end{array}$ \\
\hline $\begin{array}{l}\text { Age } 12-18 \\
\text { (teenager) }\end{array}$ & $\begin{array}{l}\text { Teenager stage: } \\
\text { The psychological tendencies are transferred from external } \\
\text { things to inner world, from the cognition of external } \\
\text { world to the experience of self-personality. }\end{array}$ & $\begin{array}{l}\text { With strong ability of independent thinking and } \\
\text { behaving, the children like competitive sports } \\
\text { and popular physical training, which have } \\
\text { certain risks and challenges. It starts to turn } \\
\text { to cultural, recreational activities, together with } \\
\text { all-round development of thinking ability. }\end{array}$ \\
\hline
\end{tabular}

\subsection{Children's Needs for Games and Time in Different Age Stages}

Children of different ages have different types of game and game mode, so their time and psychological needs will be different. Therefore, the following table integrates the needs of children of different ages for the types of games and playtime (Table 2).

\section{Findings}

Through the field survey within the study scope, three scales are divided, which include: street space, square space and courtyard space, it analyzed the current status of the three types of spaces.

\subsection{Current Status Analysis of Street Space}

\subsubsection{Street Space}

Street space is an open space enclosed by one or two sides of the street. Lateral interface is the basic factor for the formation of street space, which is composed of continuous buildings, plants or facilities. The space on both sides of the street forms a continuous space organization and order, with the continuity as their 
Table 2. Charts of games and time for children in different ages.

\begin{tabular}{|c|c|c|c|c|c|c|}
\hline Age & Types of Game & Game partner & Game mode & Playtime & Self-care Degree & Gaming space \\
\hline $\begin{array}{l}\text { Younger } \\
\text { than } 1.5\end{array}$ & $\begin{array}{l}\text { chairs, sandpit, } \\
\text { lawns, squares }\end{array}$ & $\begin{array}{l}\text { Cannot play } \\
\text { independently }\end{array}$ & $\begin{array}{l}\text { Must be } \\
\text { protected and } \\
\text { cared by adults }\end{array}$ & $\begin{array}{l}\text { Average } 2 \\
\text { hours of outdoor } \\
\text { playtime per day }\end{array}$ & dependently & $\begin{array}{l}\text { Playing near the } \\
\text { square or parklands } \\
\text { at the entrance } \\
\text { of a housing unit }\end{array}$ \\
\hline $\begin{array}{c}\text { Age } \\
1.5-3.5\end{array}$ & $\begin{array}{l}\text { chairs, sandpit, } \\
\text { lawns, squares. } \\
\text { Regular games } \\
\text { apparatus fitting } \\
\text { for kids the most }\end{array}$ & $\begin{array}{l}\text { Play alone, } \\
\text { sometimes play } \\
\text { with other } \\
\text { children }\end{array}$ & $\begin{array}{l}\text { Must be protected } \\
\text { and cared } \\
\text { by adults }\end{array}$ & $\begin{array}{l}\text { Average } 2 \text { - } 3 \\
\text { hours of outdoor } \\
\text { playtime per day }\end{array}$ & $\begin{array}{l}\text { Half can be } \\
\text { independent in a } \\
\text { decentralized } \\
\text { playground }\end{array}$ & $\begin{array}{l}\text { Playing near the } \\
\text { square or parklands } \\
\text { at the entrance } \\
\text { of a housing unit }\end{array}$ \\
\hline $\begin{array}{c}\text { Age } \\
3.5-5.5\end{array}$ & $\begin{array}{l}\text { Swings often, } \\
\text { like to play with a } \\
\text { variety of toys. } \\
\text { More sand } \\
\text { playtime for } \\
\text { kids elder than } 4\end{array}$ & $\begin{array}{l}\text { Participation in } \\
\text { companion games, } \\
\text { the number of } \\
\text { companions } \\
\text { gradually } \\
\text { increased }\end{array}$ & $\begin{array}{l}\text { Playing with } \\
\text { parents or with } \\
\text { peers in group }\end{array}$ & $\begin{array}{l}\text { Average } 3 \text { hours } \\
\text { of outdoor play- } \\
\text { time per day }\end{array}$ & $\begin{array}{l}\text { Be independent } \\
\text { in a decentralized } \\
\text { playground and be } \\
\text { self-supporting in a } \\
\text { centralized } \\
\text { playground }\end{array}$ & $\begin{array}{l}\text { Exercise on } \\
\text { parklands or } \\
\text { children's } \\
\text { playground; play } \\
\text { at squares and } \\
\text { small parks }\end{array}$ \\
\hline $\begin{array}{c}\text { First and } \\
\text { second grade kids } \\
\text { of Primary School }\end{array}$ & $\begin{array}{l}\text { Gender } \\
\text { differences are } \\
\text { beginning to } \\
\text { emerge. Girls use } \\
\text { games apparatus } \\
\text { and boys play } \\
\text { hide-and-seek }\end{array}$ & $\begin{array}{l}\text { More partners } \\
\text { they have, various } \\
\text { relationship } \\
\text { includes } \\
\text { classmates and } \\
\text { friends, more } \\
\text { games are played } \\
\text { with partners }\end{array}$ & $\begin{array}{l}\text { Play in an } \\
\text { invisible } \\
\text { place in the house }\end{array}$ & $\begin{array}{l}\text { Average } 2 \text { hours } \\
\text { of outdoor } \\
\text { playtime per day }\end{array}$ & $\begin{array}{l}\text { certain } \\
\text { self-care ability }\end{array}$ & $\begin{array}{l}\text { Exercise on } \\
\text { parklands or } \\
\text { children's } \\
\text { playground; } \\
\text { play at squares } \\
\text { and small parks }\end{array}$ \\
\hline $\begin{array}{l}\text { Third and fourth } \\
\text { grade kids of } \\
\text { Primary School }\end{array}$ & $\begin{array}{l}\text { Boys like sports, } \\
\text { girls play elastic } \\
\text { band }\end{array}$ & $\begin{array}{l}\text { More partners } \\
\text { they have, various } \\
\text { relationship } \\
\text { includes } \\
\text { classmates and } \\
\text { friends, more } \\
\text { games are played } \\
\text { with partners }\end{array}$ & Partner-centered & $\begin{array}{l}\text { Average } 2 \text { hours } \\
\text { of outdoor } \\
\text { playtime per day }\end{array}$ & Independently & $\begin{array}{l}\text { Small parks, } \\
\text { Roadside } \\
\text { parklands, squares }\end{array}$ \\
\hline $\begin{array}{l}\text { Fifth and sixth } \\
\text { grade kids of } \\
\text { Primary School }\end{array}$ & $\begin{array}{l}\text { Boys like sports, } \\
\text { girls like quiet } \\
\text { games }\end{array}$ & $\begin{array}{l}\text { More partners } \\
\text { they have, various } \\
\text { relationship } \\
\text { includes } \\
\text { classmates and } \\
\text { friends, more } \\
\text { games are played } \\
\text { with partners }\end{array}$ & Partner-centered & $\begin{array}{l}\text { Average } 1 \text { hours } \\
\text { of outdoor } \\
\text { playtime per day }\end{array}$ & $\begin{array}{l}\text { Absolutely } \\
\text { Independent }\end{array}$ & $\begin{array}{l}\text { Small parks, } \\
\text { Roadside } \\
\text { parklands, squares }\end{array}$ \\
\hline
\end{tabular}

own characteristics of the streets. As the most widely distributed public space in the city, street space is an important part of urban public space, which brings a great impact on the image of the city. Street space, as a linear space, which integrated the characteristics of "dynamic" and "continuing" and the people who move in this kind of space always have a feeling of being driven and guided. Moving from one junction to another, the extension from the beginning to the end of the space strengthens the continuity of people's behavior and psychology [4]. Blocks are the places where with close relation with children's life. Child- 
friendly in block public space is the basic value of street planning.

\subsubsection{Analysis of Survey Status}

Basing on the research finding, it is found that the street space scale of Yulin East Road Community is small, generally composed of the community exterior wall and the low-rise commercial buildings, which are divided into two kinds of streets: pedestrian-vehicle diverging and pedestrian-vehicle mixed. The pedestrian-vehicle diverging streets are usually two-lane, while the pedestrian-vehicle mixed streets are usually single-lane. There has the wall paintings on the fence walls of the streets (as shown in Picture 1), enhancing the interests. It not only increases the pleasure of pedestrians, but also solidifies the community culture. It has become a symbol of Yulin East Road Community.

The streets and alleys of Yulin East Road Community mainly undertake the function of transportation. In addition, some streets and lanes also play the role of communication for community residents and daily usage, such as playing cards, playing chess, marketing stalls and so on. At present, the main users of street space are the elderly and some middle-aged people in the community, including businessmen on both sides of the street and the tourists.

Current issues: pavements are not flat, and there will have puddles on the pavements in the rainy season, affecting pedestrian, it cannot meet the safety needs of residents; it's a serious phenomenon that having something occupied the streets, mainly occupied by private cars and business stalls (as shown in Picture 2 \& Picture 3), occupying pedestrian space, so the pedestrian sidewalk is blocked; unreasonable parking of shared bicycles also reduces the safety of the sidewalk.

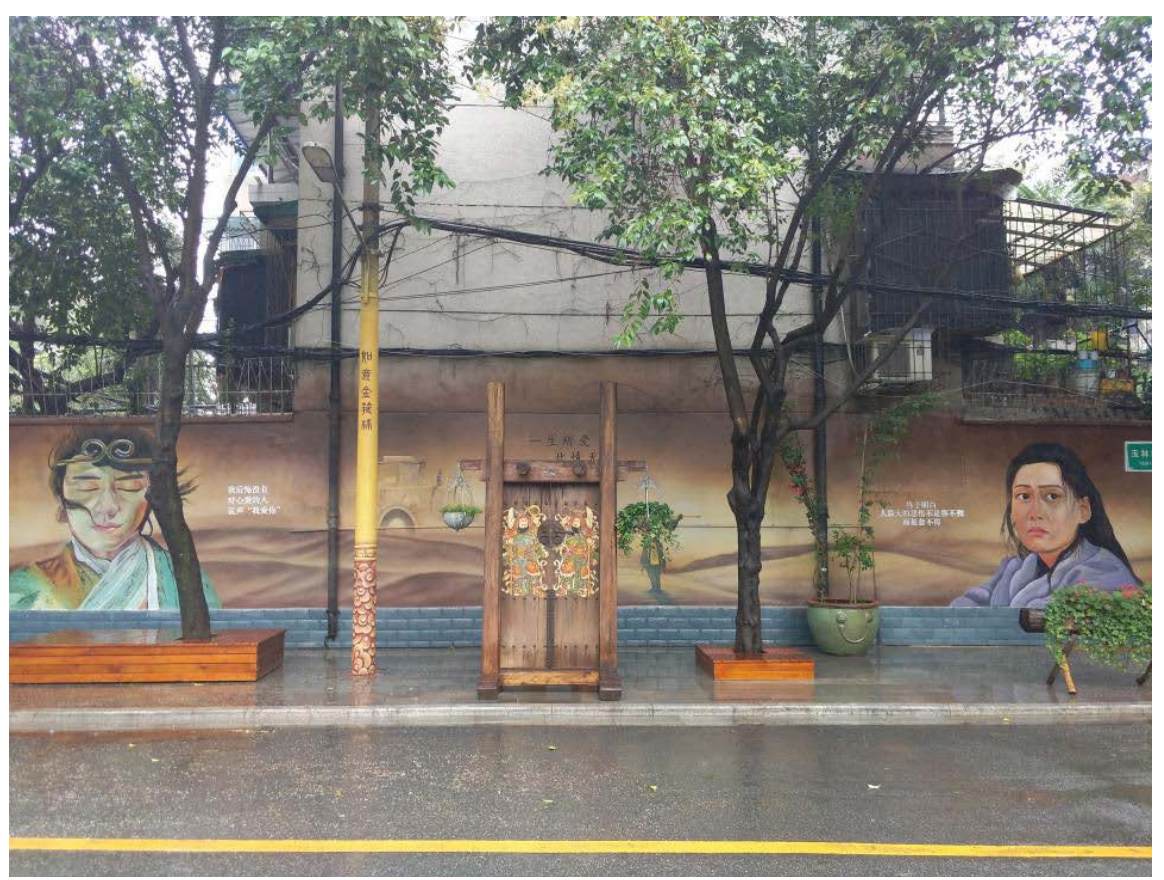

Picture 1. Photo source: Taken by author on June 11, 2018. 


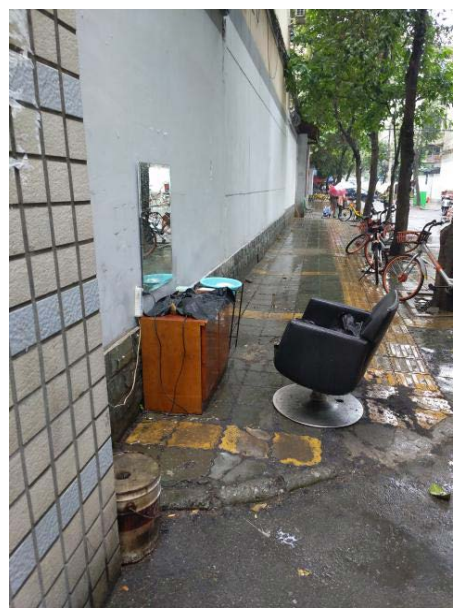

Picture 2. Photo source: Taken by author on June 11, 2018.

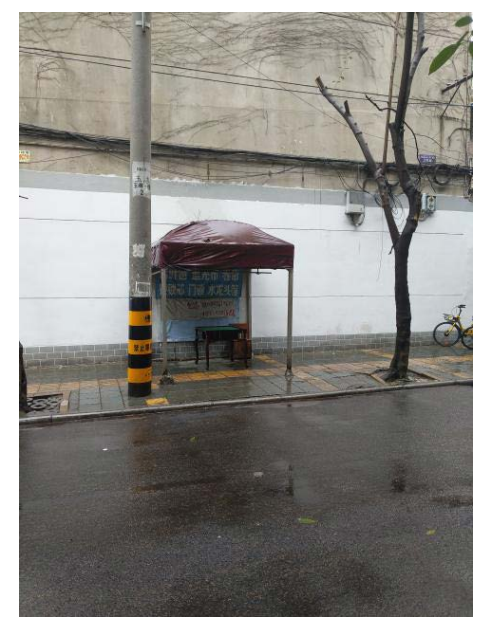

Picture 3. Photo source: Taken by author on June 11, 2018.

\subsection{Current Analysis of Courtyard Space}

The courtyard spaces of Yulin East Road Community are mainly distributed at the entrance of each courtyard inside the community. It is composed of residential buildings and courtyard walls. Most of the spatial morphology are linear strips, while a few courtyards are square, with wide spaces (as shown in Picture 4). The courtyard space serves the elderly, children and tourists in the community, meeting the needs of community residents such as communication, fitness, entertainment and leisure, and provides neighborhood residents with the function of communication, sports and children's playing. Among them, courtyard space mainly serves the children as outdoor play space.

Analysis on the current issues. Some courtyard spaces are occupied by private cars, personal items and shared bicycles in the community (as shown in Picture 5), and the per capita use area of public space are decreased, which seriously affects the traffic and fire control passageway, fails to provide children with reasonable and comfortable recreational space, and the usage rate of children space is greatly reduced. 


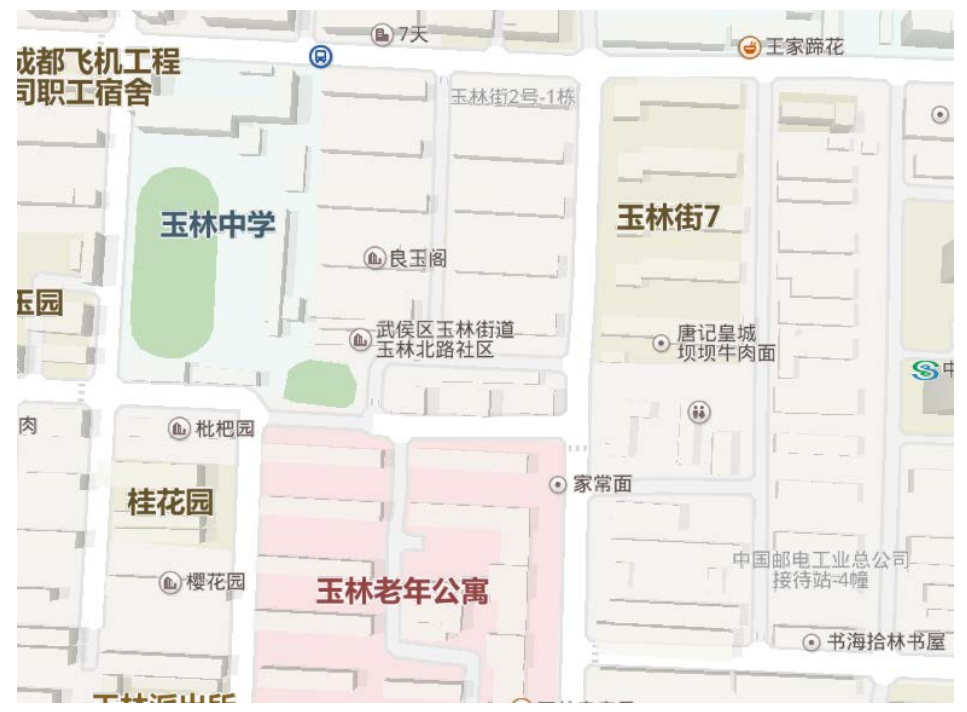

Picture 4. Photo source: Baidu map.

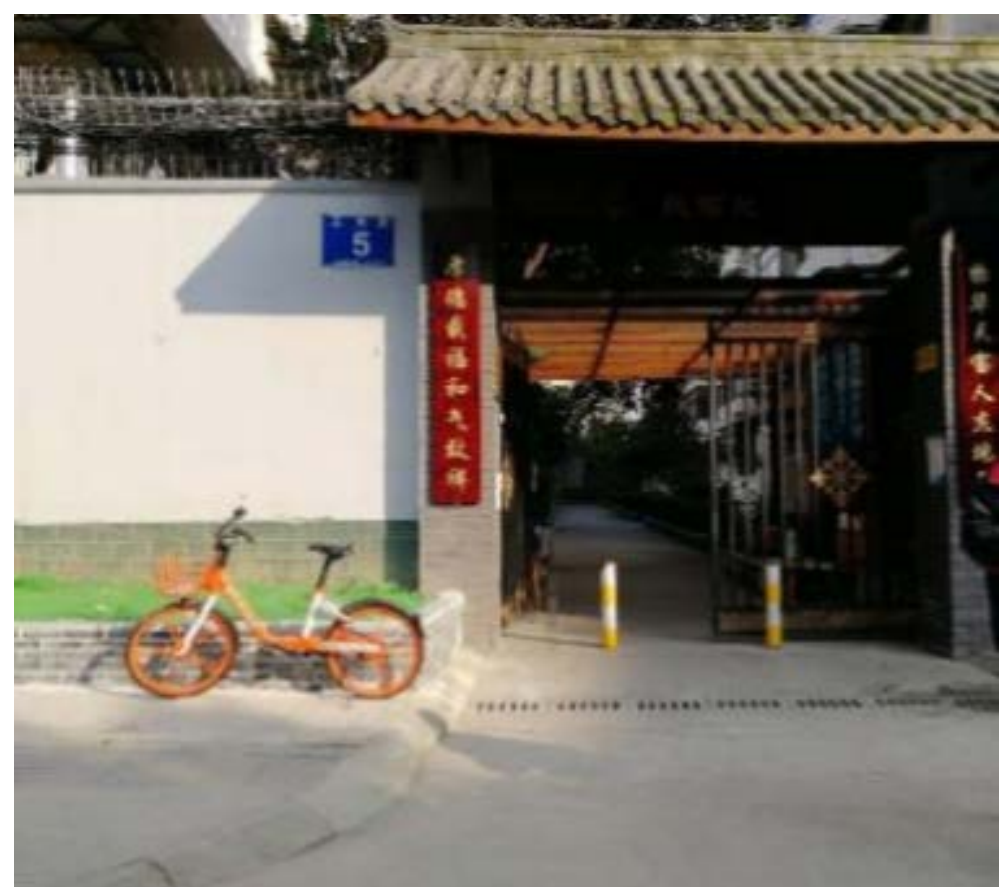

Picture 5. Photo source: Taken by author on June 11, 2018.

\subsection{Current Analysis of the Square Space}

The public square in Yulin East Road Community is in fact the open space enclosed by roads and public buildings. It is basically distributed near the service center of the community residents, and its main spatial morphology is rectangular with regular or irregular forms. The square is equipped with public infrastructure such as recreational seats, landscape pavilions, fitness facilities and so on. The main functions of the square are to meet the needs of community residents for communication, recreation, fitness, entertainment and some other needs, as the place for the activities of nearby residents. For children, the square 
also constructs some special facilities such as "hopscotch", and children's fitness facilities etc. It can also plays the role of organizing community education activities. The service objects of the square are mainly the elderly and children.

Analysis on the current issues. The square pavement is uneven, which is easy to form puddles, with part of the infrastructure damaged and its single function, it leads to the low utilization rate for children (as shown in Picture 6). Meanwhile, the square is occupied by vendors (as shown in Picture 7), which makes the reduction of the public space used by residents.

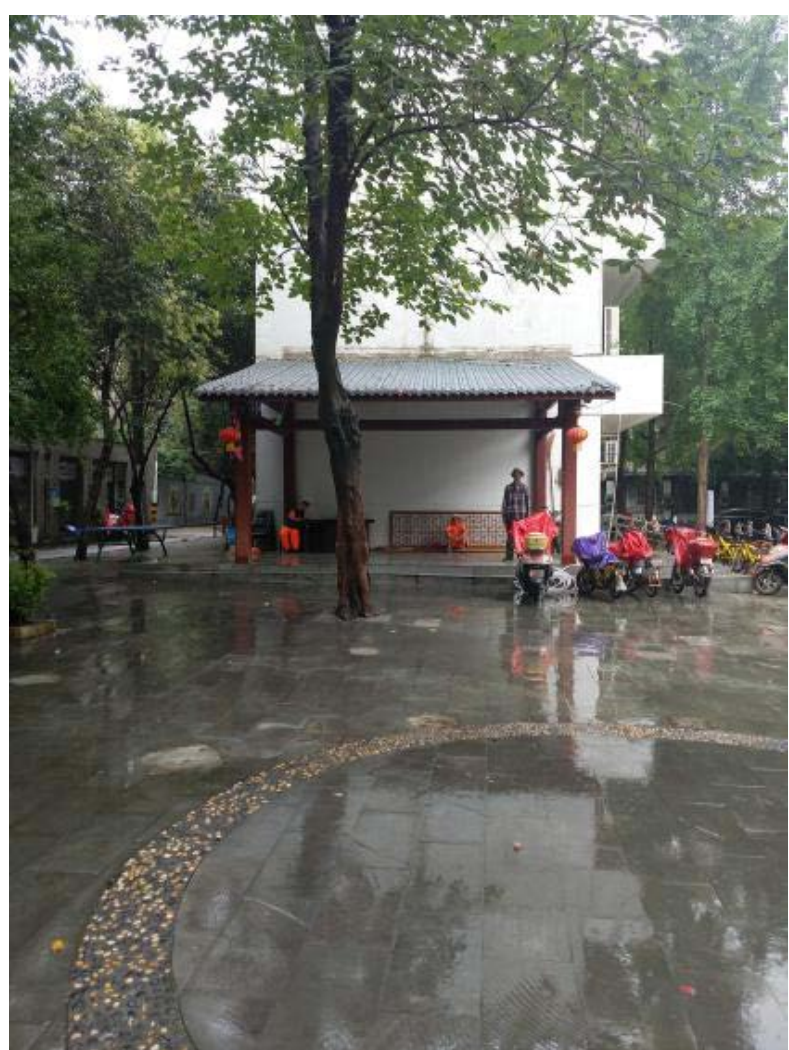

Picture 6. Photo source: Taken by author on June 11, 2018.

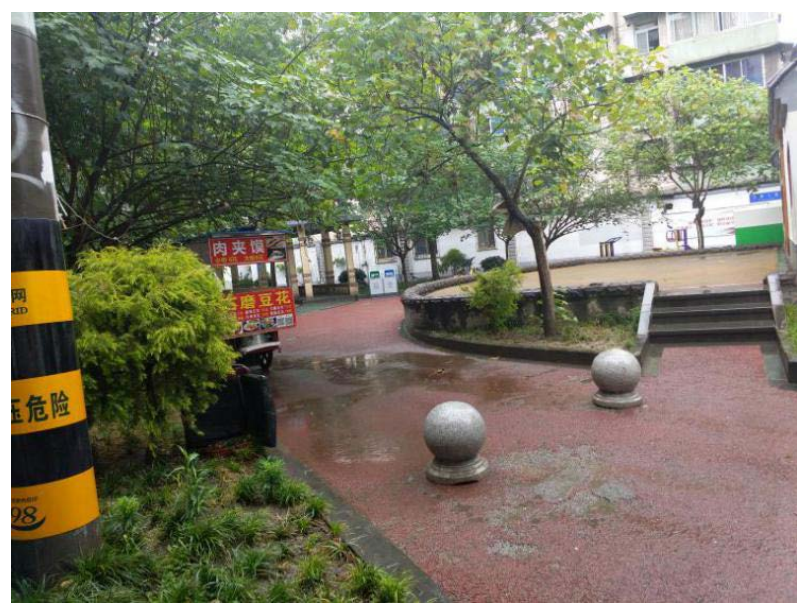

Picture 7. Photo source: Taken by author on June 11, 2018. 
In a word, the following issues exist in the public open space of Yulin East Road Community: there is contradiction between behavior requirements and spatial scale, it's a high occupied rate for the space, lacking of children's play space, with unreasonable infrastructure and low space security.

\section{Planning Proposal}

\subsection{Planning of Street Space}

Streets and alleys are the only ways which must be passed by residents, including children. They are the important generators of all kinds of communication and activities among adults and children, as the important places where are used in their daily life. Because of convenient traffic and familiar environment, children usually play close to their families, such as front steps of doors, sidewalks or streets. As early as 1924, the first survey on children's playing environment in Osaka, Japan, conducted by architect Aoya Royal (大屋霊城), found that children spent more time in the street than in the park [5]. Streets and the street corners are important meeting places for children. Street play is a worldwide cultural phenomenon [6]. Most of the outdoor activities for the children in different age stages are carried out on both sides of residential streets or alleys. Even if the road traffic is busy and the playing environment is bad, well-designed playgrounds cannot completely replace the convenience of the streets and alleys which can be used at any time. With the improvement of people's quality of life, the number and types of toys owned by children are increasing, and the playing mode of children is also changed, which is also an important factor to be considered in planning and design.

\subsubsection{Overall Consideration and Reasonable Layout}

Children's playing space on street is an important part of children's outdoor activity space. Reasonable planning and arrangement will improve the quality of children's outdoor activities [7]. The choice of street playing space is closely related to the status of streets in the whole community transportation system, the width of streets themselves, the relationship with residential areas and the location of primary schools. These factors should be fully considered in the planning and design of children's street playing space, so as to achieve overall consideration and reasonable layout.

Therefore, in the setting of the project, we should first ensure the safety of child street playing according to the location of the street, the possibility of vehicles entering, the traffic volume per hour and the speed of the car. Generally, the traffic volume on the streets for living is small and the speed is slow, which won't pose a serious threat to children's activities. If necessary, pedestrian and lanes should be separated appropriately with barriers, plants and so on. On this basis, according to the width of the road, the distribution of nodes, the current status of the existing game facilities or space, combined with the user's including the children's behavior track, activity needs and some other aspects, the playing 
space of the whole street will be systematically planned.

All in all, the street playing space should be systematic and holistic in the determination of the overall structure relationship, the distribution of entertainment venues and the creation of playing space.

\subsubsection{Safety Control}

Safety Control is an unavoidable important issue for street playing, and it is also the key point of the design. Considering the security control of street games, the playing space should be set up based on different road levels. Generally speaking, we should control the traffic volume of cars to 30 or less per hour and the speed to 10 kilometers per hour or less on the streets for children playing. If any street which will reduce the traffic and speed below this standard, it can be used as a street for children playing. On the contrary, we should arrange the playing space reasonably according to the activity rule of children, while setting up the game facilities and entertainment venues, ensure the safety of the space and design the corresponding protective facilities. For some urban expressways, we should try our best to reduce the interest that will attract the children for staying and playing, so as to avoid traffic accidents.

\subsubsection{The Principle of Combining Playing Facilities both Centralized and Decentralized}

Children's street games are distributed in a decentralized state, which is related to the linear spatial morphology of streets and the distribution of interest points that attract children to start games. Such examples are common existed among the residents of all ages in the community. Basketball courts, flower beds and a series of other recreational facilities are spread all over the block. These scattered venues are connected by the sidewalks on which people like to stroll on, with the pavement widened and a group of seats set on both sides of the streets.

In the design of street playing space for children, combining with the potential child game lines and the space types around streets and alleys, it will be taken as another key point in the design of street playing space to observe and investigate children's living habits and their activities in the street, to rationally combine game facilities, to coordinate their decentralization and centralized layout, and to create a game space corresponds to the psychological characteristics of children.

\subsubsection{Improving Traffic Quality and Stimulating Potential Vitality of Blocks}

The traffic quality of the blocks directly affects children's outdoor activities. There are three strategies will be applied to improve the block traffic: one is to completely block the traffic in the children's playground; the other is to partially block the traffic and only the central functional zone is allow it to passed through; the third one is that the traffic won't be blocked, instead, with the organization and planning of the traffic at this time to start with the planning of the children's playing environment. 


\subsection{Planning of Square Space}

In order to provide enough entertainment facilities for children, the design and transformation of partial space can be carried out. The factors such as space scale, space morphology, color, material, light environment and furniture display should be all considered as a whole, such as the setting up of some entertainment facilities and interactive space.

Set up an exploration field with various patterns. Give full play to children's exploratory instinct and form a changeable and developing environment in the exploratory field, where children can learn, play and communicate.

Set up rock climbing facilities. Through climbing, the physical fitness and perseverance of children will be exercised to meet their needs of good movement and communication. Different forms of climbing facilities will pose various challenges to children.

A spacious boulevard will be set up. It mainly provides comfortable recreational space for parents who are accompanying with children and ensuring children's play and safety.

\subsection{Planning of Courtyard Space}

The courtyard space is a place close to the residential area of the community, with small spatial scale. We should first meet the needs of children's safety and avoid the affecting of obstacles in the space on children's activities [8]. For the newly built courtyard space, all of the factors such as overall and local sizes, natural and material environment, interaction between children and other groups, and social and public policies will be considered as a whole. Entertainment facilities such as "Tree Room Nest"-Private semi-circular seats, surrounded by existing large trees can be set up around suitable scales of corners or vegetation. Children can climb, wander and jump in the tree house according to the fluctuation of height in the network system to challenge height and sensitivity. Set aside a certain space for vegetation planting platform for child participation and $\mathrm{Pa}-$ renting. For the old residential areas, we need to take into account the location choice, layout mode, service radius, accessibility and other elements of space. At the same time, we need to consider the current status and needs of children, and build a multi-functional, hierarchical and scaled activity space to improve the layout of public space in the old residential areas.

\section{Conclusion}

The public activity space of the community is a kind of extra-curricular activity space outside of children's learning. Its space environment has an important influence on children's psychological development. The outdoor activity space of the community is one of the space types with the highest accessible for children, while the outdoor space of Yulin community lacks suitable places for children's recreation and entertainment. In addition to the above design suggestions for the centralized space, children's place identity for the community should also be 
constructed at the psychological level [9]. Some self-management environment should be reserved for children to enhance their sense of place identity. For example, free toys are placed at children playgrounds for their free entertainment. Encouraging the public participation of children and empowering them with the right of environmental management for the enhancement of their place identity. The public activity space of the community is a kind of extra-curricular activity space outside of children's learning. Its space environment has an important influence on children's psychological development. The outdoor activity space of the community is one of the space types with the highest accessible for children, while the outdoor space of Yulin community lacks suitable places for children's recreation and entertainment. In addition to the above design suggestions for the centralized space, children's place identity for the community should also be constructed at the psychological level [9]. Some self-management environment should be reserved for children to enhance their sense of place identity. For example, free toys are placed at children playgrounds for their free entertainment. Encouraging the public participation of children and empowering them with the right of environmental management for the enhancement of their place identity. As a designer in the new era, it has been our continuous goal to focus on and strive for the children's psychological needs and design a community public space which will safeguard the safety use of children. As a designer in the new era, it has been our continuous goal to focus on and strive for the children's psychological needs and design a community public space which will safeguard the safety use of children.

\section{Conflicts of Interest}

The author declares no conflicts of interest regarding the publication of this paper.

\section{References}

[1] Liu, L. and Lei, Y.C. (2018) Exploration and Views of Child-Friendly Policy in Community Planning: A Case Experiment of Child-Friendly Community Pilot in Shenzhen. Urban Architecture, 4.

[2] Zhang, Y. (2007) Requirements of Children Aged 3 to 10 for Activity Environment Facilities in Residential Areas. Tongji University, Shanghai, 51.

[3] Qin, L.F. and Yang, J.Y. (2018) Survey on the Planning Strategy of Public Activity Space in Primary School Based on the Demand of Children Psychological Development. Architecture and Culture, 4.

[4] Zhou, K. and Jiao, H. (2009) Research on the Control of Continuity about Urban Street Lateral Interface. Journal of Hebei University of Engineering (Natural Science Edition), 26, 49-53

[5] Xian, T.M. (1996) Design of Child Playing Environment. Garden City Cultural Enterprise Co., Ltd., Taipei, 87.

[6] Zhan, Y. (2005) Research on the Design of Children Playground in Urban Open Space. Chongqing University, Chongqing.

[7] Lin, Y. and Dong, J. (2018) Research on City Block Public Space Planning Strategy 
Base on Child-Friendly. Journal of Xí an University of Architecture and Technology (Editions of Social Science), 37.

[8] Huang, J. (2016) Space of Children and Children in Space: Multidisciplinary Research and Enlightenment. Educational Research and Experiments, No. 3, 21-26.

[9] Lin, Y. (2014) Planning and Design of Open Space in Child-Friendly Cities: Enlightenment from Open Space in Child-Friendly Cities Abroad. Modern Urban Research, No. 11, 36-41. 